\title{
ARTIGO \\ AS EMENTAS E OS RECURSOS DIDÁTICOS EMPREGADOS NO ENSINO SOBRE TECNOLOGIA ensaIO DO DNA RECOMBINANTE EM UM CURSO DE LICENCIATURA EM CIÊNCIAS BIOLÓGICAS
}

\author{
Anna Clara da Costa Oliveira ${ }^{1}$ \\ http://orcid.org/0000-0002-0091-756X \\ Flavia Venancio Silva ${ }^{2}$ \\ http://orcid.org/0000-0003-2339-229X \\ 1. Universidade do Estado do Rio de Janeiro, Faculdade de Formação de \\ Professores, São Gonçalo, RJ, Brasil. \\ ${ }^{2}$ Universidade do Estado do Rio de Janeiro, Departamento de Ciências - \\ Faculdade de Formação de Professores, São Gonçalo, RJ, Brasil.
}

\section{RESUMO:}

O DNA recombinante, assunto abstrato do currículo de Biologia, se não for devidamente abordado pelos professores, poderá ocasionar entendimento distorcido sobre suas implicações técnicas, sociais e éticas. Este trabalho teve como objetivo investigar o tema DNA recombinante nas ementas do Curso de Licenciatura em Ciências Biológicas de uma universidade pública localizada no estado do Rio de Janeiro, e conhecer a metodologia empregada para o ensino do tema. Na pesquisa, optou-se pela análise das ementas que compõem o curso na instituição e a utilização de entrevistas com dez licenciandos do quarto ano e com um docente que ministra a disciplina Genética Molecular. Os resultados revelaram que das cinco ementas que mencionam assuntos relacionados ao DNA recombinante, uma disciplina tinha sido lecionada nos últimos cinco anos. Os principais recursos didáticos apontados pelos participantes da pesquisa foram livro, filme e site na internet. A maioria das aulas sobre o assunto foi expositiva com o uso de slides, ilustrações, artigos, textos, vídeos e práticas demonstrativas.

Palavras-chave: Formação de Professores; Tecnologia do DNA recombinante; Ensino de Genética.

\section{EL PROGRAMA Y LOS RECURSOS DIDÁCTICOS UTILIZADOS EN LA ENSEÑANZA DE LA TECNOLOGÍA DEL ADN RECOMBINANTE EN UNA CARRERA DE PROFESORADO EN CIENCIAS BIOLÓGICAS}

\section{RESUMEN:}

El tema del ADN recombinante, un asunto abstracto del plan de estudios de la carrera de Biología, si los profesores no lo abordan adecuadamente, puede conducir a una comprensión distorsionada de sus implicaciones técnicas, sociales y éticas. Este trabajo tuvo como objetivo investigar el tema del ADN recombinante en los programas de las asignaturas de la Carrera de Profesorado en Ciencias Biológicas de una universidad pública ubicada en el estado de Río de Janeiro, y conocer la
Palabras clave: Formación del profesorado; Tecnología de ADN recombinante; Enseñanza de la Genética. 
metodología utilizada para enseñar el tema. En la investigación se optó por el análisis de los programas que componen la carrera en la institución y el uso de entrevistas con diez estudiantes de cuarto año y con un profesor que imparte la asignatura de Genética Molecular. Los resultados revelaron que de los cinco programas que mencionan temas relacionados con el ADN recombinante, una asignatura había sido impartida en los últimos cinco años. Los principales recursos didácticos señalados por los participantes de la investigación fueron el libro, películas y sitios en Internet. La mayoría de las clases sobre el tema fueron expositivas con el uso de diapositivas, ilustraciones, artículos, textos, videos y prácticas demostrativas.

\title{
THE MENU AND RESOURCES USED IN TEACHING ABOUT RECOMBINANT DNA TECHNOLOGY IN A LICENSING COURSE IN BIOLOGICAL SCIENCES
}

\author{
ABSTRACT:
}

Recombinant DNA, an abstract subject of the Biology curriculum, if not properly addressed by teachers, can lead to a distorted understanding of its technical, social and ethical implications. This work aimed to investigate the theme of recombinant DNA in the syllabus of a Teacher Training Course in Biological Sciences from a public university located in the state of Rio de Janeiro, and to know the methodology used to teach the theme. In the research, we opted for the analysis of the syllabus that make up the course at the institution and the use of interviews with ten fourth-year undergraduates and with a professor who teaches the discipline of molecular genetics. The results revealed that of the five syllabuses that mention issues related to recombinant DNA, one discipline had been taught in the last five years. The main teaching resources pointed out by the research participants were book, film and website. Most classes on the subject were expository, with the use of slides, illustrations, articles, texts, videos and demonstrative practices.

Keywords:

Teacher

Education;

Recombinant

DNA technology;

Genetics

Teaching.

\section{INTRODUÇÃO}

No final do século XX, estudos sobre clonagem de animais e o Projeto Genoma Humano (HGP), dentre outros, levantaram importantes questões éticas e sociais sobre as aplicações destas tecnologias. Para o entendimento destas questões, é importante que o ensino de Genética seja feito de forma adequada na Educação Básica, no entanto, pesquisas em nível internacional têm revelado baixa compreensão dos alunos sobre Genética e suas tecnologias em vários níveis de ensino. Uma pesquisa com discentes indianos do Ensino Médio feita por Chattopadhyay (2005) revelou que seus conhecimentos sobre Genética estavam aquém do esperado. $\mathrm{O}$ autor defendeu a ideia de que os estudantes com compreensão sobre Genética e suas tecnologias podem compreender pesquisas e suas aplicações em relação às questões sociais, legais e éticas. Seguindo a mesma linha de pesquisa, os resultados alcançados por Oliveira (2018) corroboraram o que foi observado por Chattopadhyay (2005). Neste caso, o estudo foi realizado com alunos do $3^{\circ}$ ano do Ensino Médio no estado do Ceará, onde os estudantes apresentavam dificuldades sobre conceitos básicos de Genética. Neste mesmo 
sentido, Kawashima (2015) mostrou que os estudantes do $2^{\circ}$ e $3^{\circ}$ ano do Ensino Médio no estado do Paraná, também tinham conhecimentos insatisfatórios sobre Genética, no entanto, após a aplicação do material "O jogo da Memória: Onde está o Gene?", houve melhoria na assimilação dos conceitos.

Considerando a Base Nacional Comum Curricular - BNCC (MEC, 2018), os assuntos relacionados à tecnologia do DNA recombinante devem ser abordados na licenciatura para que os futuros docentes sejam bem informados e possam abordar essa temática na Educação Básica. Ressaltamos que a BNCC recomenda como competência em Biologia, que o aluno deve analisar, argumentar, e posicionar-se criticamente em relação a temas de Ciência e Tecnologia, por exemplo, produção de alimento transgênico, manipulação genética em saúde e outros. Contudo, para o aluno ter o posicionamento crítico, é importante que a educação seja problematizadora. De acordo com Freire (1987), esta concepção almeja o pensamento autêntico e que não pode ser imposta, ou seja, não se assemelha à concepção de uma educação bancária, na qual os discentes recebem passivamente o conhecimento, consequentemente memorizando os conteúdos trabalhados em sala de aula e realizando repetições. Logo, os futuros docentes devem estar capacitados para proporcionar momentos de discussão e reflexão com os alunos, com vistas ao desenvolvimento de senso crítico sobre a realidade.

Desta forma, é importante que nas escolas, os estudantes tenham acesso às informações concernentes à tecnologia do DNA recombinante para relacioná-las com o cotidiano. Por exemplo, os estudantes deveriam ser informados sobre o significado de um triângulo amarelo com a letra $\mathrm{T}$ preta na embalagem de alguns alimentos para sinalizar ao consumidor a presença de ingrediente transgênico. Isso ocorre desde 2003, quando o Governo Federal liberou o plantio de soja transgênica no país. A escola é o local mais apropriado para que os jovens se apropriem desse conhecimento, pois eles consomem diariamente produtos resultantes da aplicação do DNA recombinante. Além disso, se os estudantes são informados sobre o que é um transgênico, eles poderiam compreender discussões como a que ocorreu em abril de 2018 no Senado Federal do Brasil sobre um projeto de lei para o fim da obrigatoriedade do selo que indica na embalagem de alimentos a presença de ingrediente transgênico.

Entretanto, para a aprendizagem do estudante sobre a tecnologia do DNA recombinante, é importante levar em consideração o seu conhecimento prévio, que é a chave da aprendizagem significativa, como afirma David Ausubel. Ou seja, relacionar o conteúdo científico com as experiências vividas pelo aluno, podendo proporcionar uma aprendizagem profunda, na qual o conteúdo trabalhado pelo professor não será apenas dados memorizados pelos educandos, mas servirá para que os alunos interpretem a realidade que os rodeia (Ronca, 1994).

Entender sobre a molécula de DNA, é necessário para compreender o conceito, aplicações e como é realizado o processo da tecnologia do DNA recombinante. Partindo do pressuposto que a aprendizagem não é mecânica, não é apenas uma transmissão daquele professor que ensina, para o aluno que aprende. Então, para viabilizar o processo de aprendizagem sobre o DNA recombinante, o professor pode lançar mão de diferentes estratégias didáticas.

Barbosa et al. (2015) elaboraram uma sequência didática envolvendo o tema DNA através de ferramentas audiovisuais, um filme Gattaca, experiência de extração de DNA e a utilização de estratégias pedagógicas. Barbosa et al. (2015) criaram essa sequência didática a partir do seu estudo com 116 alunos do $3^{\circ}$ ano do Ensino Médio de uma escola pública localizada na Baixada Fluminense, no estado do Rio de Janeiro. Os autores observaram que as concepções dos estudantes sobre o DNA antes de ingressarem no curso de Biotecnologia apresentavam fragilidades em relação a temas científicos. 
Como exemplos de estratégias didáticas desenvolvidas por docentes a fim de criar condição para os alunos avançarem na construção de seu conhecimento sobre DNA recombinante, Ovigli et al. (2009) desenvolveram um espaço Interativo na Coordenadoria de Educação e Difusão Científica do Centro de Biotecnologia Molecular Estrutural - CBME, apresentando uma sala dedicada à Biotecnologia, tendo modelos da bactéria E. coli, utilizada como vetor em Biotecnologia, e dois painéis, sendo um deles relativo à tecnologia do DNA recombinante e aplicações desta técnica para obtenção de hormônios do crescimento e insulina. Galhardi (2015) desenvolveu um material audiovisual sobre clonagem através de recortes de filmes, vídeos e imagens, presentes no Portal Dia-a-Dia Educação do estado do Paraná, para ser aplicado com alunos do $3^{\circ}$ ano do Ensino Médio do estado. Ainda sobre o tema, Meloni et al. (2018) realizaram um jogo de tabuleiro investigativo e cooperativo, para os alunos participarem de um laboratório de biotecnologia, onde enfrentavam como desafio, a fabricação da vacina recombinante contra o HPV (Papiloma Vírus Humano), através da técnica do DNA recombinante. Assim, cumprindo com o papel da divulgação científica acerca da Biotecnologia.

Os diferentes exemplos citados demonstram que há diferentes ferramentas que os professores podem utilizar para viabilizar o processo de ensino-aprendizagem. Com isso, podemos reforçar que "O uso de materiais didáticos no ensino escolar deve ser sempre acompanhado de uma reflexão pedagógica quanto a sua verdadeira utilidade no processo de ensino-aprendizagem para que alcance o objetivo proposto" (Souza, 2007, p. 113).

O presente estudo teve como objetivo investigar se o tema DNA recombinante é mencionado nas ementas das disciplinas do Curso de Licenciatura em Ciências Biológicas da Faculdade de Formação de Professores (FFP) da Universidade do Estado do Rio de Janeiro (UERJ) localizada no município de São Gonçalo e conhecer a metodologia empregada pelos docentes para o ensino do tema.

\section{ASPECTOS METODOLÓGICOS}

\section{Delineamento da pesquisa}

Foi realizada uma pesquisa que com base nos seus objetivos podemos caracterizá-la como exploratória de acordo com Gehardt \& Silveira (2009), pois buscamos conhecer melhor o problema a ser investigado na instituição pesquisada. A referida pesquisa foi aprovada pelo Comitê de Ética em Pesquisas com Seres Humanos - CEP da Universidade do Estado do Rio de Janeiro com o parecer de número 3.456.786. As técnicas de pesquisa utilizadas foram: pesquisa documental (Cellard, 2012) e entrevistas (Gehardt \& Silveira, 2009).

\section{Pesquisa documental}

A escolha metodológica para a análise das ementas do curso de Licenciatura em Ciências Biológicas do Departamento de Ciências da instituição pesquisada, foi qualitativa tipo documental. De acordo com Cellard (2012), este é um método analítico que visa mapear as informações e organizar os acontecimentos através dos documentos preexistentes.

A análise documental ou análise preliminar das ementas foi realizada a partir das cinco dimensões propostas por Cellard (2012): (1) O contexto - contexto no qual foi produzido e aqueles a quem ele é destinado, (2) $\mathrm{O}$ autor ou os autores - elucidar a identidade do autor, (3) A autenticidade e a confiabilidade do texto - procedência do documento, (4) A natureza do texto - estrutura do texto e (5) Os conceitos-chave e a lógica interna do texto - termos empregados pelo autor ou autores de um texto. 
Inicialmente em 2019 foi acessado o site da instituição de ensino superior para obter as ementas. Foram coletadas 48 ementas das disciplinas obrigatórias e 21 das eletivas restritas ao Curso de Ciências Biológicas. Posteriormente, foi realizada uma leitura das ementas com o intuito de verificar e selecionar as disciplinas que apresentavam inserção do tema tecnologia do DNA recombinante e como se relacionavam com os objetivos da disciplina. A partir desta leitura, foram observadas as ementas que mencionavam assuntos relacionados à tecnologia do DNA recombinante.

Após a seleção dessas ementas, foi realizada uma análise documental e os dados foram agrupados conforme as cinco dimensões propostas por Cellard (2012). Em seguida à análise preliminar, foi feita uma análise do conteúdo e do objetivo das ementas a partir dos termos empregados pelos autores, e estes foram organizados em categorias iniciais e finais.

\section{A entrevista semiestruturada e os sujeitos da pesquisa}

A entrevista é uma técnica de interação social, uma forma de diálogo assimétrico, em que uma das partes busca obter dados e a outra se apresenta como fonte de informação. A vantagem da entrevista é que permite o esclarecimento do que foi perguntado ao entrevistado e por isso tem grande chance de se conseguir as respostas do participante. Na entrevista semiestruturada as questões são previamente organizadas, no entanto é permitido que o participante fale sobre os desdobramentos do tema principal (Gehardt \& Silveira, 2009).

Neste trabalho, foram realizadas entrevistas semiestruturadas após a assinatura do Termo de Consentimento Livre e Esclarecido (TCLE) pelos participantes da pesquisa. Os sujeitos da pesquisa foram dez licenciandos do Curso de Licenciatura em Ciências Biológicas da universidade pesquisada, sendo seis mulheres e quatro homens, inscritos na disciplina obrigatória Projeto I do segundo semestre de 2019, onde o total de alunos era dezoito. A escolha por Projeto I, se deu pelo fato dessa disciplina ser cursada por licenciandos que estão elaborando seu projeto de monografia para conclusão do curso. Os participantes responderam as seguintes perguntas: a) "Conhece referências bibliográficas, vídeos, jogos ou outros recursos didáticos que abordam o DNA recombinante?" e b) "Quais recursos didáticos seus professores utilizaram para abordar esse conteúdo?". As entrevistas foram gravadas e transcritas, e para preservar a identidade dos participantes, mas identificá-los por suas narrativas, foram atribuídas a cada um, nomes fictícios. Os dados obtidos foram analisados qualitativamente, para descrever os sentidos contidos nas explanações, a fim de compreender o que os licenciandos conheciam e pensavam sobre o DNA recombinante e como as reflexões resultantes da análise desses dados poderiam auxiliar para a melhoria da formação docente inicial. Para complementar a pesquisa, também foi realizada uma entrevista com um docente responsável pela disciplina obrigatória Genética Molecular que aborda a tecnologia do DNA recombinante.

\section{A análise de conteúdo da entrevista}

Para a análise dos resultados alcançados com as entrevistas, utilizamos a técnica de Análise de Conteúdo proposta por Bardin (2012). Foi feita uma leitura de todas as entrevistas transcritas, quando em uma primeira análise foi feita uma leitura atenta às respostas, buscando a percepção do todo. Após a tomada de conhecimento dos dados, as similaridades de particularidades nas respostas à entrevista foram discriminadas. Seguida a essa etapa, foram criadas categorias de análise de dados para o agrupamento das respostas. Posteriormente, os dados foram interpretados buscando alinhá-los com os referenciais teóricos. 


\section{DISCUSSÃO DOS RESULTADOS}

\section{Análise das ementas}

A análise das ementas demonstrou que dentre as 48 disciplinas do Curso de Licenciatura em Ciências Biológicas, cinco disciplinas relacionavam o tema da tecnologia do DNA recombinante. Apenas uma destas disciplinas era obrigatória e nomeada como Genética Molecular; as outras eram disciplinas eletivas restritas ao Curso de Ciências Biológicas, denominadas de Fundamentos da Engenharia Genética, Micologia Aplicada, Princípios de Biotecnologia e Microbiologia Ambiental, dentre as 21 eletivas. Após a análise, os dados das ementas foram agrupados conforme as cinco dimensões propostas por Cellard (2012), os quais estão listados abaixo (Figura 1).

\section{Figura 1: Levantamento de dados das ementas das disciplinas de um Curso de Licenciatura em Ciências Biológicas}

\begin{tabular}{|c|c|}
\hline Dimensões & Itens identificados \\
\hline Os autores & $\begin{array}{l}\text { Docentes do Departamento de Ciências (DCIEN) da Faculdade de Formação de } \\
\text { Professores (FFP) da Universidade do Estado do Rio de Janeiro (UERJ). }\end{array}$ \\
\hline $\begin{array}{l}\text { O contexto - } \\
\text { objetivos das } \\
\text { ementas }\end{array}$ & $\begin{array}{l}\text { Formar professores de Ciências Naturais para o ensino fundamental e Biologia } \\
\text { para o ensino médio, através dos seguintes objetivos: } \\
\text { Genética Molecular: Introduzir o aluno aos principais conceitos de Genética } \\
\text { Molecular. } \\
\text { Fundamentos de Engenharia Genética: Introduzir o aluno em metodologias } \\
\text { utilizadas em Engenharia Genética, definindo suas aplicações em medicina, } \\
\text { agropecuária, criminalistica e suas interaçōes com os diversos ramos da biologia } \\
\text { moderna. } \\
\text { Micologia Aplicada: Conhecer a diversidade do Reino Fungi e compreender os } \\
\text { diversos aspectos de utilização de fungos na Biotecnologia moderna: processos } \\
\text { industriais, médico-farmacológicos, agrícolas e relacionados ao ambiente. } \\
\text { Microbiologia Ambiental: Conhecer a diversidade de microrganismos, o papel } \\
\text { desempenhado por estes nos diferentes ecossistemas da biosfera e a relaçăo } \\
\text { destes com outros organismos. } \\
\text { Principios de Biotecnologia: Compreender a importância e o impacto da } \\
\text { Biotecnologia no dia a dia, e sua perspectiva nas Ciências Biológicas. }\end{array}$ \\
\hline A autenticidade & $\begin{array}{l}\text { Documento homologado pelo Departamento de Orientaçăo e Supervisăo } \\
\text { Pedagógica (DEP) - UERJ. }\end{array}$ \\
\hline A natureza & $\begin{array}{l}\text { Texto estruturado a partir de carga horária total, carga horária semanal referente } \\
\text { a aulas teóricas, prática/trabalho de campo, laboratório e pré-requisito. }\end{array}$ \\
\hline $\begin{array}{l}\text { A lógica interna } \\
\text { do texto - } \\
\text { conteúdo das } \\
\text { ementas }\end{array}$ & $\begin{array}{l}\text { A ementa é estruturada com conteúdo especifico que atenda aos seus objetivos: } \\
\text { Genética Molecular: DNA: estrutura quimica, histórico. Replicaçăo do DNA, } \\
\text { Replicação "in vitro" (PCR). Elementos genéticos: plasmideos, transposons, ilhas } \\
\text { de patogenicidade. Estrutura dos cromossomos eucarióticos e divisão celular. } \\
\text { Estrutura gênica, transcrição e traduçăo. Mutação. } \\
\text { Fundamentos de Engenharia Genética: A estrutura do DNA e dos Genes, o } \\
\text { DNA como principio transformante. Isolamento e manipulaçăo do DNA. } \\
\text { Engenharia Genética: principais ferramentas. Estudos sobre a variabilidade } \\
\text { genética: sequenciamento do DNA, bancos de sequência, Projeto Genoma } \\
\text { Humano e de microrganismos. A técnica do PCR. Bioética: clonagem, uso de } \\
\text { células tronco, transgênicos. O uso da bioinformática em Engenharia Genética. } \\
\text { Micologia Aplicada: Estudo dos fungos sob os aspectos históricos, taxonômico, } \\
\text { morfológico, reprodutivo e ecológico. Fisiologia e estratégias nutricionais: } \\
\text { saprofitismo, parasitismo, simbiose. Metabolismo fúngico primário e secundário. } \\
\text { Diversidade metabólica. Influência dos fatores ambientais: temperatura, umidade, } \\
\text { aerobiose/ anaerobiose, pH. Cultivo de fungos: técnicas de laboratório para } \\
\text { isolamento, preservação, propagação e fermentaçăo. Bromatologia e toxicologia: } \\
\text { fungos e nutrição humana. Valor nutricional dos fungos. Fungos tóxicos. } \\
\text { Micologia médica e veterinária. Principais patógenos. Micologia agronômica. } \\
\text { Principais patógenos. Fungos na indústria alimentícia. Fungos do solo e } \\
\text { associações biológicas. Fixação de nutrientes e decomposiçăo. } \\
\text { Microbiologia Ambiental: Diversidade dos microrganismos nos diferentes } \\
\text { ambientes solo, ar e água, o papel desempenhado por estes nos ciclos biológicos } \\
\text { dos elementos nos ecossistemas, as interações entre os microrganismos e } \\
\text { destes com outros organismos, a participação dos microrganismos na poluição } \\
\text { ambiental e sua utilização na biotecnologia. Trabalho de campo. } \\
\text { Principios de Biotecnologia: Importância da Biodiversidade para a } \\
\text { Biotecnologia. Tópicos de Engenharia Genética. Os Organismos Transgênicos, a } \\
\text { clonagem e o papel da Biossegurança. A Bioética e a Biotecnologia. Atividades } \\
\text { laboratoriais. }\end{array}$ \\
\hline
\end{tabular}


Fonte: elaborada pelas autoras.

Após a análise documental, categorias iniciais foram elaboradas a partir dos termos, relacionados à tecnologia do DNA recombinante, encontrados nos objetivos e nos conteúdos das ementas (Figura 2). Posteriormente, foram criadas duas categorias finais denominadas: 1) Técnica e 2) Aplicação (Figura 2).

$\mathrm{Na}$ categoria final - Técnica - constam as unidades de registro relacionadas aos procedimentos, ou seja, metodologias que possibilitam aos licenciandos a compreensão sobre os conceitos científicos e o que é a tecnologia do DNA recombinante. Na categoria final Aplicação - encontram-se as unidades de registro que expressam os produtos gerados pela tecnologia do DNA recombinante, que tenham como propósito esclarecer os graduandos sobre o uso desta tecnologia pela sociedade.

Figura 2. Categorias temáticas das ementas das disciplinas de um Curso de Licenciatura em Ciências Biológicas

\begin{tabular}{|c|c|c|}
\hline Disciplinas & Categorias Iniciais & Categorias Finais \\
\hline Genética Molecular & $\begin{array}{l}1 \text { - Genética Molecular } \\
2 \text { - Plasmídeo }\end{array}$ & \multirow{4}{*}{ I - Técnica } \\
\hline \multirow{2}{*}{$\begin{array}{l}\text { Fundamentos da Engenharia } \\
\text { Genética }\end{array}$} & 3 - Metodologia em Engenharia Genética & \\
\hline & \multirow{2}{*}{ 4-Engenharia Genética } & \\
\hline Princípios da Biotecnologia & & \\
\hline $\begin{array}{l}\text { Fundamentos da Engenharia } \\
\text { genética }\end{array}$ & $\begin{array}{l}5 \text { - Aplicações em engenharia genética } \\
6 \text { - Transgênicos }\end{array}$ & \multirow{4}{*}{ II - Aplicaçăo } \\
\hline Princípios da Biotecnologia & 7 -Impactos da biotecnologia & \\
\hline Micologia aplicada & $\begin{array}{l}8 \text { - Diversidade e utilização dos fungos } \\
9 \text { - Micologia aplicada }\end{array}$ & \\
\hline Microbiologia Ambiental & $\begin{array}{l}10 \text { - Diversidade de microrganismos } \\
11 \text { - Biotecnologia }\end{array}$ & \\
\hline
\end{tabular}

Fonte: elaborada pelas autoras.

A disciplina Genética Molecular foi agrupada na categoria Técnica, enquanto Fundamentos da Engenharia Genética e Princípios de Biotecnologia se agruparam nas categorias Técnica e na Aplicação. Portanto, essas duas últimas são disciplinas que buscam o diálogo entre o conhecimento das técnicas utilizadas pela Engenharia Genética e os produtos gerados que podem ser utilizados pela sociedade, como os transgênicos. Ao passo que Genética Molecular, é mais centrada nas técnicas, ou seja, nas ferramentas como plasmídeos que permitem a manipulação dos genes. Além disso, foi possível observar que as outras duas eletivas restritas, Micologia Aplicada e Microbiologia Ambiental, foram agrupadas na categoria Aplicação. As disciplinas agrupadas nesta segunda categoria, possibilitam aos licenciandos ampliar suas visões sobre as aplicações da Engenharia Genética com base no conhecimento da diversidade genética dos seres vivos em busca de soluções para demandas da sociedade. 
As disciplinas Genética Molecular, Fundamentos da Engenharia Genética e Princípios de Biotecnologia foram agrupadas na categoria Técnica com base no conteúdo das ementas. Isso corroborou a análise dos objetivos de Genética Molecular e Fundamentos de Engenharia Genética, cujos descritores encontrados já apontavam um caráter voltado para as técnicas. No caso de Fundamentos de Biotecnologia, os descritores encontrados em seus objetivos apontaram um caráter focado na Aplicação. Dessa forma, para classificar as disciplinas em categorias finais, os descritores observados nos objetivos e no conteúdo das ementas foram combinados.

Por fim, foi observado que as eletivas foram agrupadas na categoria Aplicação, confirmando o que já havia sido constatado com a análise dos objetivos de suas ementas. Dessa forma, as eletivas Fundamentos da Engenharia Genética e Princípios de Biotecnologia possivelmente buscam proporcionar aos alunos uma relação entre os conhecimentos das técnicas de Engenharia Genética e suas aplicações na sociedade, enquanto Micologia Aplicada e Microbiologia Ambiental focam na diversidade dos microrganismos e sua aplicação, combinada ou não à Engenharia Genética.

Portanto, esses dados levantados apontam que o curso apresenta em sua estrutura curricular, disciplinas que podem ser oferecidas aos licenciandos a fim de prepará-los para construir uma concepção crítica do que é e para que serve a Engenharia Genética e suas repercussões na vida das pessoas. Esses aspectos são indispensáveis à formação docente inicial, pois os futuros professores precisam de uma formação que lhes dê segurança para abordar questões que relacionam Ciência, Sociedade e Tecnologia ao lecionarem para estudantes do Ensino Básico.

Após a análise documental, verificou-se com a coordenação do Curso de Licenciatura em Ciências Biológicas da instituição pesquisada, que das cinco disciplinas analisadas, Genética Molecular é a que tem sido oferecida aos licenciandos em Ciências Biológicas e as demais não tinham sido lecionadas nos últimos cinco anos. Diante deste fato, procurou-se entrevistar o professor da referida disciplina para compreender melhor como a Tecnologia do DNA recombinante tem sido abordada no curso.

Seguindo a mesma linha de pesquisa desenvolvida no presente trabalho, os autores Fauziah e Putri (2019) analisaram o currículo (análise dos planos de aprendizagem semestral) e entrevistaram professores e alunos do Programa de Estudos em Educação em Biologia da Universidade Islâmica de Riau, localizada na Indonésia. Na análise curricular, os autores observaram que os planos de estudo apresentavam dez tópicos sobre a Biotecnologia. Tais resultados demonstraram certas semelhanças aos da presente pesquisa no que tange aos descritores que foram encontrados nas ementas e que permitiram classificar as disciplinas em duas categoriais finais, uma com caráter de técnica e outra como aplicação.

Fauziah e Putri (2019) apontaram que o plano curricular analisado tinha uma boa cobertura de material, boa linguística e uma boa apresentação, mas faltava a apresentação de pesquisas recentes e um suporte de material didático. Ao entrevistarem os docentes de Ciências Biológicas, os autores apontaram dois obstáculos: o primeiro é que os professores não elaboram o módulo de suas próprias aulas e o segundo dizia respeito à falta de referências para os graduandos estudarem sobre biotecnologia. Os autores supracitados sinalizaram a importância da análise do currículo, da elaboração de materiais didáticos, dos procedimentos de ensino e das pesquisas sobre o tema para melhorar o processo de aprendizagem dos alunos.

Com o objetivo específico de "identificar, a partir da visão dos licenciandos, a presença de temas relacionados à Biotecnologia no seu curso", Corrêa e Galieta $(2020$, p. 121) realizaram um estudo com discentes do $1^{\circ}$ ao $7^{\circ}$ período do Curso de Licenciatura em Ciências Biológicas da FFP-UERJ matriculados no segundo semestre de 2014. As autoras sinalizaram que 43 futuros professores de Ciências e Biologia "não identificaram temas de Biotecnologia em nenhuma das 
disciplinas cursadas" e que os participantes associaram temas de Biotecnologia com disciplinas pedagógicas. Além disso, os participantes apontaram temas prioritários a serem abordados com seus futuros alunos, os quais parecem desfavorecer um discurso mais contextualizado e crítico.

$\mathrm{Na}$ presente pesquisa, ao perguntar ao docente da disciplina obrigatória Genética Molecular as questões "A disciplina eletiva Fundamentos de Engenharia Genética é oferecida?" e "Qual a sua motivação para lecionar sobre esse conteúdo?", o professor retratou em sua fala, alguns problemas relacionados à infraestrutura, condições de trabalho, organização de conteúdo, metodologias de ensino e o uso de recursos pedagógicos para aulas práticas. O docente fez uso de expressões como: falta de materiais, falta de verba, carga horária e espaço físico para demonstrar alguns entraves que vivenciava.

Ao analisar a fala do docente, percebe-se que ele quer oferecer a disciplina eletiva sobre a tecnologia do DNA recombinante e realizar aulas práticas com os alunos, mas por falta de condições, isso não tem acontecido. Os aspectos apontados pelo professor entrevistado corroboram os relatos de Firmino (2007), o qual sinalizou que as principais dificuldades dos professores em ministrar aulas sobre temas relacionados à Biotecnologia são as condições de materiais, tempo para aulas práticas, falta de experiência e conhecimento aprofundado.

Algumas pesquisas relacionadas ao ensino de Biotecnologia e Engenharia Genética têm apontado limitações em questões genéticas e biotecnológicas por parte de estudantes e professores, assim como, falta de infraestrutura nas instituições para o ensino desses temas.

$\mathrm{Na}$ presente pesquisa, o docente entrevistado mostrou-se desestimulado com as circunstâncias que envolvem seu trabalho. Mesmo diante de todas as problemáticas vivenciadas por ele, o professor nos últimos três semestres tinha realizado atividades nas aulas de Genética Molecular com alguns enfoques em aplicações, o que denota sua preocupação em contextualizar os conceitos científicos apresentados aos alunos:

"O que eu fiz para tentar sanar esse problema de não oferecer Fundamentos de Engenharia Genética... Eu trabalho as ferramentas de Engenharia Genética que seriam os reagentes, enzimas de restrição, função das principais enzimas, os vetores, os plasmídeos, os principais métodos, os iniciais, as primeiras ferramentas, método de clonagem, método de transformação bacteriana. Depois falo sobre sequenciamento de genomas, falo de PCR, mas lá na replicação do DNA. Tem uma parte da aula só de PCR... E, além disso, faço uma aula de aplicações da Engenharia Genética, que aí já falo de vacina, de transgênico, de clones, célula tronco..." (Docente, grifo nosso).

Observamos que a ação do docente em querer ensinar os conhecimentos sobre o DNA recombinante e sua tecnologia é importante para a formação inicial docente. Os futuros professores deverão ministrar aulas sobre tecnologia do DNA recombinante no Ensino Básico, e tais conhecimentos são essenciais para promover a alfabetização científica dos estudantes na escola. O docente entrevistado justificou sua motivação para lecionar sobre esse tema, como a seguir:

"Minha motivação... porque é a minha vida praticamente, a vida toda" (Docente).

O estudo realizado por Orhan e Sahin (2018) com professores de Ciências, apontou que as atividades laboratoriais envolvendo a tecnologia do DNA recombinante aperfeiçoaram os conhecimentos dos docentes sobre aplicações e tecnologias do DNA. Os autores afirmaram a importância da integração da teoria com a prática no ensino de Engenharia Genética, e quando os discentes conseguiram desempenhar um papel ativo no laboratório envolvendo os 
procedimentos, o processo de ensino e aprendizagem foi efetivo. Esses dados reforçam a ideia defendida pelo docente entrevistado na presente pesquisa de que o ensino de Genética Molecular deve agregar aulas expositivas às práticas experimentais em laboratório com o intuito de oferecer melhores condições aos alunos para compreenderem as técnicas usadas na Engenharia Genética voltadas à construção de produtos biotecnológicos.

Os relatos de Venturini et al. (2018), os quais avaliaram o emprego de aulas práticas como método de ensino sobre "Enzimas de restrição, reação em cadeia da polimerase (PCR) e eletroforese em gel de agarose", assim como, "Transformação bacteriana por eletroporação e seleção de clones", apontam que os discentes conseguiram descrever e explicar os procedimentos em questão e discorreram sobre seus desdobramentos. Estes autores concluíram que o emprego desta metodologia em Genética Molecular, contribuiu com a aprendizagem dos estudantes, motivando-os e tornando-os protagonistas. No presente estudo, durante a entrevista com o docente, ele disse o seguinte:

Utilizo Data show. Esse período comecei e vou continuar fazendo. Eu consegui fazer uma aula prática nessa sala que eu te falei. Eu levei a máquina de PCR pra lá, levei voltímetro, levei cuba de eletroforese pra lá e fiz uma prática lá de extração de DNA, eletroforese e PCR... (Docente).

Nesta fala acima, o professor reconhece a importância da realização de práticas experimentais que informem os licenciandos sobre as técnicas usadas em Engenharia Genética. No entanto, durante a entrevista, ele relatou que esta prática não foi realizada em todos os semestres, mas ele deseja realizá-la mais vezes em Genética Molecular.

Seguindo a mesma linha de pensamento, Firmino (2007) afirma que os docentes apresentam uma percepção de que a ausência de aulas práticas adequadas são obstáculos para o ensino e aprendizagem. No entanto, na falta de condições de atividades práticas, é possível oferecer aulas teóricas, jogos, vídeos, dentre outros recursos para explicar as técnicas utilizadas em Biotecnologia e suas aplicações na sociedade.

A pesquisa realizada por Faváro et al. (2003) com professores do Ensino Médio da rede pública estadual de São Paulo, nos municípios de Botucatu e São Manuel, apontou que os participantes estavam desanimados e cansados devido às condições de trabalho. Da mesma forma, na presente pesquisa foi constatada uma certa frustração do docente entrevistado quando ele diz: "isso acabou me desmotivando a oferecer a disciplina". O mesmo pode ser visto em outros países, por exemplo, Earthman e Lemasters (2009) apontaram a frustração dos professores em escolas dos Estados Unidos, os quais sentem-se negligenciados a tal ponto de relatarem que estavam dispostos a deixar a profissão. Neste mesmo trabalho, os autores apontaram que as autoridades escolares precisam reconhecer a importância que as condições físicas têm sobre os docentes e que esses sentimentos de frustação podem influenciar no ensino e aprendizagem dos estudantes. Diante do exposto, percebemos que a insatisfação com a infraestrutura permeia o Ensino Básico e Superior.

Em contrapartida, outra pesquisa realizada com professores de Cotabato nas Filipinas por Usop et al. (2013), mostrou que os docentes estavam satisfeitos com suas condições de trabalho, políticas escolares, supervisão, remuneração, relações interpessoais, oportunidades de promoção, crescimento, desempenho, reconhecimento e responsabilidade. Além disso, esses professores apresentavam alto nível de habilidades relacionadas ao desempenho, iniciativas e produtividade. Desta forma, os autores ressaltaram que se professores estão satisfeitos com seu trabalho, eles irão manter o nível de desempenho e isso terá implicações positivas no processo de ensino aprendizagem. 


\section{Entrevista com os licenciandos}

Após a entrevista com os dez licenciandos em Ciências Biológicas da referida instituição pesquisada, suas respostas às perguntas - a) "Conhece referências bibliográficas, vídeos, jogos ou outros recursos didáticos que abordam o DNA recombinante?" e b) "Quais recursos didáticos seus professores utilizaram para abordar esse conteúdo?" - foram organizadas em onze categorias iniciais e posteriormente agrupadas em três categorias finais (Figura 3).

Figura 3. Recursos pedagógicos sobre a tecnologia do DNA recombinante conhecidos pelos licenciandos ${ }^{*}=$ respostas para "Conhece referências bibliográficas, vídeos, jogos ou outros recursos didáticos que abordam o DNA recombinante?" e \# = respostas para "Quais recursos didáticos seus professores utilizaram para abordar esse conteúdo?”)

\begin{tabular}{|c|c|c|}
\hline Categorias Iniciais & Categorias Finais & $\mathbf{N}^{\circ}$ de licenciandos \\
\hline 1. Livro & \multirow{8}{*}{ I-Recursos didáticos } & \multirow{4}{*}{$5^{\star}$} \\
\hline 2. Filme & & \\
\hline 3. Artigo & & \\
\hline 4. Texto & & \\
\hline 5. Jogo & & \multirow{4}{*}{ 4\# } \\
\hline 6. Video & & \\
\hline 7. Imagem & & \\
\hline 8. Site & & \\
\hline 9. Aula expositiva & \multirow{2}{*}{ II - Metodologia } & \multirow{2}{*}{ 2\# } \\
\hline 10. Aula prática & & \\
\hline \multirow[t]{2}{*}{ 11. Năo } & \multirow{2}{*}{$\begin{array}{l}\text { III - Não conhecem recursos } \\
\text { didáticos ou năo lembram se } \\
\text { seus professores utilizaram } \\
\text { tais ferramentas pedagógicas }\end{array}$} & $5^{*}$ \\
\hline & & $4 \#$ \\
\hline
\end{tabular}

Fonte: elaborada pelas autoras.

Cinco licenciandos relataram que os principais recursos didáticos que eles conheciam e que abordavam o DNA recombinante eram os livros, os filmes e sites, os quais foram agrupados na categoria final "I - Recursos didáticos". Além disso, quatro licenciandos apontaram que os recursos didáticos utilizados pelos professores para ensinar Engenharia Genética foram: slides, ilustrações, jogos, livros, vídeos, artigos e textos, os quais também compuseram a categoria I. A seguir encontram-se trechos das entrevistas com os licenciandos que citaram recursos didáticos para Engenharia Genética:

"Livro eu conheço aquele de Biologia Celular que eu vi no primeiro período ... e jogos não conheço não" (Kátia, grifo nosso).

"É tinha um livro que era o gene. [...] meu professor de Genética ele usava como base para dar as aulas dele" (Anna Beatriz, grifo nosso). 
"Conheço um site que fala sobre o DNA que foi até uma professora que me recomendou" (Julianna, grifo nosso).

Getúlio apontou o filme X-Men como uma ferramenta, conforme a seguir:

"Sim. Eu acredito que até uns filmes podem abordar esse tema como foi o caso do filme bastante conhecido que é X-Men, né?! Dá para abordar bastante essa questão do DNA recombinante" (Getúlio, grifo nosso).

Há um equívoco na fala de Getúlio, pois o filme que citou aborda a história de humanos que detêm habilidades especiais devido às mutações genéticas em seu DNA e não à tecnologia do DNA recombinante. Com o intuito de facilitar a mediação de conceitos em Genética e temas afins, Nascimento et al. (2016), criaram um Guia do educador para o filme $\mathrm{X}$-Men Primeira Classe, no intuito de orientar atividades didáticas no ensino de genética através de um roteiro, por meio de recortes do filme e materiais complementares.

Tendo em vista que os conceitos genéticos são normalmente de difícil compreensão por parte dos estudantes, Machado (2012) produziu um catálogo de filmes como sugestão didática para os professores utilizarem em suas aulas de Genética. Dentre os filmes que podem ser utilizados estão: $O$ sexto sentido (clonagem de organismos multicelulares, bioética, clonagem terapêutica, programa de triagem populacional, DNA recombinante e organismos transgênicos), A ilha (clonagem terapêutica, clonagem e bioética), Ultravioleta (organismos transgênicos) e Homem Aranha (organismos transgênicos).

Em um estudo realizado na Turquia com licenciandos de Biologia, Acarli (2016) relatou que parte dos estudantes não faziam associações conceituais adequadas a respeito da Engenharia Genética. $\mathrm{O}$ autor ainda ressaltou que a aprendizagem de conceitos é resultado da interação do conhecimento científico ensinado com o conhecimento do cotidiano. Esse fato corroborou o que foi observado na fala de Getúlio na presente pesquisa, quando o participante confundiu mutações genéticas no DNA de um personagem do filme X-Man com um processo de recombinação genética feita a partir de técnicas de Engenharia Genética. Embora a ideia do licenciando de usar um filme como recurso didático para o ensino de DNA recombinante seja muito boa, em sua fala, ele demonstrou desconhecimento de um filme adequado ao tema e isso provavelmente se deu ao fato dele não ter se apropriado corretamente do conceito científico ou do que se trata o filme.

Diante deste contexto, cabe aos docentes do Ensino Superior planejarem suas aulas sobre Engenharia Genética, de modo que os alunos não sejam estimulados somente a decorar conceitos, mas que busquem compreendê-los e relacioná-los com a biotecnologia. Tais licenciandos precisam associar determinados produtos biotecnológicos aos desdobramentos de pesquisas aplicadas às demandas da sociedade e aos interesses econômicos de determinados grupos. Para alcançar este propósito, os docentes podem acessar e também orientar os licenciandos para pesquisar na internet diversos artigos disponíveis que apontam o desenvolvimento de técnicas para a manipulação de materiais genéticos alavancando a indústria da biotecnologia para a produção de vacinas de DNA (Diniz \& Ferreira, 2010), biofármacos (Brandão \& Souza, 2015), melhoramento genético de plantas e animais (Soares de Paula et al., 2017), produção de enzimas de interesses biotecnológicos na indústria alimentícia, de papel e celulose, têxtil, farmacêutica e o uso de microrganismos para o desenvolvimento de tecnologias mais eficazes (Monteiro \& Silva, 2009).

O estudo realizado por Ribeiro et al. (2017) em Portugal, com estudantes do Ensino Médio, utilizou um kit de ensino sobre técnicas de biotecnologia aplicadas ao rastreamento genético, onde foi feita uma simulação no contexto da série popular Game of Thrones da HBO. Os autores usaram tal estratégia a fim de desafiar os estudantes e estimular suas 
habilidades. Eles buscaram uma experimentação que considerasse não apenas o campo teórico, mas também todas as técnicas, sendo um dos focos as técnicas de manipulação do DNA. Esse exemplo de atividade, traz reflexões sobre a relevância de um ensino robusto sobre Biologia Molecular e as técnicas de manipulação genética durante a formação inicial de licenciandos em Ciências Biológicas. Caso contrário, os futuros professores não estarão preparados para lançar mão de estratégias de ensino que valorizem o protagonismo dos alunos no Ensino Básico. Para tal atribuição, eles precisam receber treinamento sobre as técnicas de manipulação de DNA e conhecer possíveis transposições didáticas para a realização de experimentação no âmbito escolar.

Como ferramenta pedagógica, Halimah et al. (2019), utilizaram vídeo para investigar o domínio do conceito de tecnologia do DNA recombinante com 50 alunos que participaram de cursos de biotecnologia na Indonésia. Os participantes responderam a um pré-teste, com questões relacionadas à tecnologia do DNA recombinante, pesquisaram e baixaram vídeos sobre tal assunto no Youtube e responderam a um pós-teste. Os resultados apontaram que houve melhora significativa dos alunos em relação aos conceitos trabalhados. Diante deste fato, o uso de vídeos disponíveis no YouTube mostrou-se como mais um recurso de apoio ao ensino sobre tecnologia do DNA recombinante nas escolas e universidades. Para isso, o professor deverá realizar uma seleção prévia dos vídeos adequados à abordagem que se propõe a realizar com os alunos.

As respostas de dois participantes à pergunta "Quais recursos didáticos seus professores utilizaram para abordar esse conteúdo?", foram agrupadas na categoria final "II - Metodologia" (Figura 3). As metodologias utilizadas pelos professores que foram citadas pelos participantes foram aula expositiva e aula prática. Algumas respostas sobre as metodologias apresentavam expressões como: "Muito pouco", "Não me lembro de nenhum", "Não lembro nem de experimento". Embora tenham dito isso, os licenciandos citaram alguns recursos didáticos, o que foi bem positivo. Por exemplo, as falas de seis participantes demostraram o uso de diferentes recursos pedagógicos pelo docente como listado a seguir:

"Livros mesmo. Só referências bibliográficas. Não chegou a passar nenhum vídeo, nem nada fora do padrão de livros e referências, textos e artigos" (Getúlio, grifo nosso).

"Eu acho que jogos. Faz muito tempo. Lembro só do professor falando mesmo. Assim, do livro, dando referencial, mas a aula sempre foi expositiva não lembro nem de experimentos, ele trazia coisas que vinha do laboratório. Teve uma aula que ele trouxe, mas nada que a gente fizesse, ele trazia se fosse algo mais expositivo mesmo. Aula expositiva" (Anna Beatriz, grifo nosso).

"Olha, não lembro muito bem. Mas eu acho que usaram de vídeos, alguns, né?! E práticas também" (Joanna, grifo nosso).

"Vimos pouco em Genética Molecular. Foi só uma aulinha bem curtinha. Um tópico assim da aula. Uma imagem ou outra, mas nada demais. Tudo muito curtinho" (Jonas, grifo nosso).

"Eu só tive aulas mesmo teóricas, muito pouco. Nesse caso do site, né?! Que é um site de animações. Então, é como se você tivesse dentro da célula mesmo, vendo o DNA, aí tem a replicação, tudo, mas não lembro de nenhum jogo didático, vídeo ou algo assim a mais nas aulas" (Julianna, grifo nosso).

"Olha! Eu não lembro direito, mas só explicação mesmo, só explicação oral e alguns slides, demostrando algumas imagens. Nada muito aprofundado, não" (Mônica, grifo 
nosso).

Com a mesma finalidade de conhecer as metodologias utilizadas no ensino de Genética, Silva et al. (2019) entrevistaram doze professores de Biologia da rede pública estadual da cidade de Teresina, estado do Piauí. Os autores observaram que o livro didático era o material didático mais usado entre os docentes envolvidos na pesquisa; a segunda ferramenta pedagógica eram sites educacionais, e o terceiro recurso eram textos e vídeos aulas. Silva et al. (2019) afirmaram que os artigos científicos eram poucos utilizados pelos docentes, menos da metade dos professores entrevistados recorriam a este recurso, e os que usavam era só para tirar dúvidas pontuais. Uma parcela de $80 \%$ dos docentes realizavam atividades práticas como extração de DNA e observação de lâminas para a visualização de cromossomos com o microscópio e 33,3\% das atividades relatadas eram lúdicas. O presente estudo corroborou o que foi relatado por Silva et al. (2019), pois as falas dos licenciandos sinalizaram semelhança de alguns recursos usados pelos docentes nas aulas.

Considerando que a utilização dos recursos didáticos deve ser mediadora de práticas pedagógicas, para o auxílio do processo de ensino-aprendizagem, dos dez participantes desta pesquisa, cinco responderam que não conheciam recursos didáticos para o ensino sobre DNA recombinante. Essas respostas se agruparam na categoria final "III - Não conhecem recursos didáticos ou não lembram dos professores utilizarem ferramentas pedagógicas". Além disso, quatro licenciandos responderam que tecnologia do DNA recombinante não foi um assunto abordado nas disciplinas cursadas e por isso não citaram recursos didáticos utilizados por seus professores; tais respostas também foram agrupadas na categoria III (Figura 3).

Esses dados são preocupantes, pois indicam que estes estudantes carecem de informações sobre o DNA recombinante. Provavelmente isso ocorreu porque as disciplinas eletivas não estavam sendo oferecidas, ou esse tema não foi abordado nas disciplinas sobre Ensino de Biologia.

Quanto aos licenciandos que não tiveram aulas sobre o assunto, suas respostas estão a seguir: "Não foi abordado ainda. Vai ser abordado" (Gilson), "Não utilizaram. Não tive esse conteúdo de DNA recombinante" (Gabriela), "Eu acho que não me lembro de nenhum" (Jairo), "Nossa! Não faço ideia" (Kátia). Estes dados corroboram uma carência de alguns participantes com relação ao conhecimento de materiais didáticos e estratégias pedagógicas que poderiam futuramente subsidiar suas aulas sobre Engenharia Genética nas escolas.

\section{CONSIDERAÇÕES FINAIS}

Com base nos resultados desta pesquisa, em relação à análise das ementas, verificou-se que o curso de Licenciatura em Ciências Biológicas apresenta na sua estrutura curricular, uma disciplina obrigatória e quatro eletivas restritas ao Curso de Licenciatura em Ciências Biológicas que tratam de assuntos relacionados ao DNA recombinante. Porém, nos últimos anos, Genética Molecular foi a única disciplina ofertada aos licenciandos. De acordo com os termos contidos nos objetivos e no conteúdo da ementa desta disciplina, observou-se uma abordagem focada no fundamento das técnicas do DNA recombinante. Por outro lado, as disciplinas eletivas, conforme a análise das ementas, apresentam uma abordagem direcionada às aplicações do DNA recombinante. Este fato parece representar um entrave na formação inicial de professores de Ciências e Biologia com relação ao tema. Fundamentos de Engenharia Genética, é uma eletiva que segundo o docente entrevistado, não tem sido oferecida devido à falta de espaço para comportar alunos no laboratório onde contém os equipamentos e à falta de verba para a compra de reagentes necessários às práticas experimentais. No entanto nos últimos três semestres, compreendendo o último de 2018 e os dois de 2019, o docente conseguiu realizar 
atividades práticas demonstrativas sobre extração de DNA e sobre a Reação em cadeia da Polimerase (PCR) e contemplou expositivamente aplicações da tecnologia do DNA recombinante na disciplina de Genética Molecular contextualizando os conceitos científicos ensinados. Consideramos que tais práticas de ensino empregadas pelo docente colaboram para a formação dos futuros professores de Ciências e Biologia.

Os licenciandos participantes desse estudo, relataram durante a entrevista que os principais recursos didáticos que eles conheciam e que abordavam sobre DNA recombinante eram os livros, os filmes e sites. Os discentes também apontaram que as aulas sobre esse tema são em sua maioria expositivas, com a utilização de slides, ilustrações, artigos, textos, vídeos e práticas demonstrativas, aos quais o docente recorreu para apresentar o conteúdo de Genética Molecular. Cinco participantes não souberam citar recursos didáticos sobre a tecnologia do DNA recombinante e quatro não lembravam as ferramentas pedagógicas utilizadas pelos docentes.

Diante do exposto, recomendamos que os licenciandos em Ciências Biológicas tenham mais oportunidades de aulas teóricas e práticas, que poderiam ser oferecidas pelas disciplinas eletivas para aprofundamento dos conceitos científicos abordados em Genética Molecular. Ressaltamos que as disciplinas eletivas analisadas são bem estruturadas conforme seus objetivos e conteúdos e se oferecidas regularmente possibilitariam aos licenciandos ampliar suas visões sobre as aplicações da Engenharia Genética com base no conhecimento da diversidade genética dos seres vivos em busca de soluções para demandas da sociedade.

Ademais, recomendamos que as disciplinas que envolvem uma abordagem pedagógica, também auxiliem na construção do conhecimento dos licenciandos sobre o DNA recombinante com relação aos recursos didáticos que poderiam subsidiar o embasamento teórico na escola. Além disso, a divulgação entre os licenciandos, de artigos educacionais sobre atividades experimentais adaptadas ao ambiente escolar para reproduzir experimentos científicos como extração de DNA e eletroforese em gel para a detecção de DNA seria desejável.

Desta forma, ressaltamos a relevância dos dados apresentados pela pesquisa para o aprimoramento da formação inicial dos professores de Ciências e Biologia sobre a tecnologia do DNA recombinante e suas implicações na sociedade.

\section{AGRADECIMENTOS}

As autoras agradecem à Fundação de Amparo à Pesquisa do Estado do Rio de Janeiro (FAPERJ) pelo auxílio financeiro concedido como bolsa de estudo.

\section{REFERÊNCIAS}

Acarli, D. S. (2016). Determining prospective Biology teachers' cognitive structure in terms of "Biotechnology". Journal of Baltic Science Educaction, 15(4), 494-505.

Barbosa, J. V., Santos, S. M., Rôças, G. \& Leal, C. A. (2015). Onde fica o ácido desoxirribonucléico (DNA)? X Encontro Nacional de Pesquisa em Educação em Ciências -X ENPEC, Águas de Lindóia, SP. 
Bardin, L. (2012). Análise de Conteúdo. 1. ed. Edições 70.

Brandão, C. Z. G. S. \& Souza, J. N. (2015). Biofármacos: da pesquisa ao mercado: uma revisão da literatura. Saúde \& Ciência em Ação, 1(1), 105-118.

MEC (2018). Base Nacional Comum Curricular. Brasília: Secretaria da Educação Básica.

Cellard, A. A análise documental. (2012). In: Poupart, J.; Deslauriers, L.H., Laperriere, A., Mayer, R., Pires, A. (Org.). A pesquisa qualitativa: enfoques epistemológicos e metodológicos (pp. 295-316). Petrópolis, RJ: Vozes.

Chattopadhyay, A. (2005). Understanding of Genetic informations in Higher Secondary Students in Northeast India and the Implications for Genetics Educations. Cell Biology Education, 4(1), 97-104. https://doi.org/10.1187/cbe.04-06-0042

Correa, R. S. \& Galieta, T. (2020). Biotecnologia sob enfoque CTS: concepções de licenciandos em Ciências Biológicas. Conexões Ciência e Tecnologia, 14(2), 118-126. https://doi.org/10.21439/conexoes.v14i2.1470

Diniz, M. O. \& Ferreira, L. C. S. (2010). Biotecnologia aplicada ao desenvolvimento de vacinas. Estudos avançados, 24(70), 19-30. https://doi.org/10.1590/S0103-40142010000300003

Earthman, G. L. \& Lemasters, L. K. (2009). Teacher attitudes about classroom conditions. Journal of Educational Administration, 47(3), 323-335. https://doi.org/10.1108/09578230910955764

Fauziah, N. \& Putri, I. I. (2019). Analisis Perangkat Pembelajaran Sebagai Dasar Pengembangan Modul Bioteknologi Bermuatan Hasil Riset Untuk Mahasiswa Biologi. Jurnal Bioterdidik, 7(6), 7-13.

Fávaro, R. D., Diniz, R. E. S., Maia, I. G. \& Domingues, D. S. (2003). Engenharia Genética e Biologia Molecular: possibilidades e limites do trabalho do professor de biologia do ensino médio. IV Encontro Nacional de Pesquisa em Educação em Ciências - IV ENPEC, Bauru, SP.

Firmino, M. N. P. (2007). Biotecnologia - estudo exploratório das percepções e atitudes de professores e alunos. (Dissertação de mestrado). Faculdade de Ciências da Universidade do Porto. Porto.

Freire, P. (1987). Pedagogia do oprimido. 17. ed. Paz e Terra.

Galhardi, T. S. S. (2015). Uso de audiovisual como estratégia de ensino de Clonagem. (Monografia de Especialização). Universidade Federal do Paraná, Santo Antônio da Platina.

Gerhardt, T.E. \& Silveira, D.T. (2009). Método de Pesquisa. 1. ed. Editora da UFRGS.

Halimah, M., Rahmat, A. \& Sri, R. (2019). Use of video modeling examples to improve understanding of the concept of recombinant DNA technology for Biology teacher candidates. International Conference on Biology and Applied Science. https://doi.org/10.1063/1.5115714

Kawashima, A. B. (2015). Ensino e aprendizagem de Biologia no ensino médio e a assimilação de conceitos e biológicos. (Monografia). Universidade Federal do Paraná, Apucarama.

Machado, M. H. (2012). Uso do vídeo como ferramenta no ensino de genética. (Dissertação de mestrado). Centro Universitário de Volta Redonda, Volta Redonda. 
Meloni, J. S., Spiegel, C. \& Gomes, S. A. O. (2018). Biotecnologia em jogo: estratégia lúdica para o ensino médio. Genética na escola. 13(2), 154-183.

Monteiro, V. N. \& Silva, R. N. (2009). Aplicações Industriais da Biotecnologia Enzimática. Revista Processos Químicos/SENAI, 3(5), 9-23.

Nascimento, J. M. L., Meirelles, R. M. S., Mello e Silva, M., Nascimento, R. L. \& Barros, M. D. M. (2016). Guia do Educador para o filme X-Men Primeira Classe. Genética na Escola, $11(1), 28-35$.

Oliveira, M. G. S. (2018). A compreensão de conceitos básicos de genética por estudantes do $3^{o}$ ano do ensino médio na cidade de Aurora/CE. (Monografia). Universidade Federal de Campina Grande, Cajazeiras.

Orhan, T. Y. \& Sahin, N. (2018). The Impact of Innovative Teaching Approaches on Biotechnology Laboratory Experiences of Science Teachers. Education Sciences, 8(4), 213, 124. https://doi.org/10.3390/educsci8040213

Ovigli, F. B., Bossolan, N. R. S. \& Beltramini, L. M. (2009). Biologia molecular na educação básica: explorando possibilidades de aprendizagem em um espaço não formal. Revista Brasileira de Ensino de Bioquímica e Biologia Molecular, (1), 1-7.

Ribeiro. T., Paz, M. \& Pereira, S. (2017). Game of Genomes: Didatic adaptation of the Nature's Dice Kit (NCBE). Hands-on Science. Growing with Science, 38-45.

Ronca, A. C. C. (1994). Teorias de ensino: a contribuição de David Ausebel. Temas em psicologia, 2(3), 91-95.

Silva, C. P., Oliveira, T. C. S., Andrade, T. E. G., Reis, T. T. D. M., Pereira, C. S. \& Valente, S. E. S. (2019). O ensino de genética em escolas no nordeste da Brasileiro: uma análise docente. Ensino, Saúde e Ambiente, 12(1), 217-234.

Soares de Paula, R., Gonçalves dos Santos, K. J., Pinheiro Pales, A., da Silva Castro, C., dos Santos Lopes, J. C. \& Ferreira Daniel Santos, J. (2017). Animais transgênicos: Conceito, Metodologias e Aplicações. REDVET. Revista Electrónica de Veterinária, 18(9), 1-16.

Souza, S. E. O uso de recursos didáticos no ensino escolar. (2007). I Encontro de Pesquisa em Educação, IV Jornada de Prática de Ensino, XIII Semana de Pedagogia da UEM: "Infância e Práticas Educativas". Arquivos do Mudi, 11(2), 110-114.

Venturini, A. M., Souza, L.F., Dias, N.M.S., Monteiro-Vitorello, C.B. \& Quecine, M.C. (2018). Aulas Práticas de Laboratório como Método de Ensino de Genética Molecular. Revista de Graduação, 3(2), 81-85. https://doi.org/10.11606/issn.2525-376X.v3i2p81-85

Usop, A. M., Langguyuan-Kadtong, M. \& Sajid, A. (2013). Work Performance and Job Satisfaction among Teachers. Psychology, (3)5, 245-252. 


\section{Anna Clara da Costa Oliveira}

Mestre em Ensino de Ciências, Ambiente e Sociedade pela Universidade do Estado do Rio de Janeiro, Faculdade de Formação de Professores, São Gonçalo, RJ, Brasil.

E-mail: annaclaraoliveiraa@gmail.com

\section{Flavia Venancio Silva}

Doutora em Fitotecnia pela Universidade Federal Rural do Rio de Janeiro e membro do Núcleo de Pesquisa e Ensino de Ciências, Professora Associada da Universidade do Estado do Rio de Janeiro, Departamento de Ciências - Faculdade de Formação de Professores, São Gonçalo, RJ, Brasil.

E-mail: flavia_venancio@uerj.br

\section{Contato}

Flavia Venancio Silva

Departamento de Ciências - Faculdade de de Formação de Professores Universidade do Estado do Rio de Janeiro Rua Francisco Portela, nº 1470, Patronato. São Gonçalo, RJ/Brasil

CEP 24.435-005

Editor Responsável

Fábio Augusto Rodrigues Silva

Centro de Ensino de Ciências e Matemática de Minas Gerais - CECIMIG

Faculdade de Educação - Universidade Federal de Minas Gerais revistaepec@gmail.com 